\title{
A Study on the Effectiveness of Bracing Systems in Soft Storey Steel Buildings
}

\author{
SHALAKA DHOKANE ${ }^{1}$, K. K. PATHAK ${ }^{2}$ \\ ${ }^{1}$ PG Student, Dept. of Civil and Env. Engineering, NITTTR Bhopal, INDIA 462002 \\ ${ }^{2}$ Professor, Dept. of Civil Engineering, IIT(BHU) Varanasi, INDIA 221005 \\ E-mail: shalakadhokne07@gmail.com,kkpathak.civ@itbhu.ac.in \\ Published Online: December 28, 2016 \\ The Author(s) 2016. This article is published with open access at www.chitkara.edu.in/publications
}

\begin{abstract}
A soft storey or a weak storey is one in which the lateral stiffness is less than 70 percent of that in the storey above or it can be less than 80 percent of the average lateral stiffness of the three stories above. For the reduction of lateral deflection of a structure, a bracing system is provided. In seismic design of structure and in high rise structure, the provision of bracing system has become more effective. So this paper aims to find out the effect of bracing on soft storey of steel building. In this paper, $\mathrm{G}+9$ steel frames are modeled with different type of bracing pattern and different combination of soft story using software STAAD Pro. Effect of these different bracings on soft storey is studied for different parameter like column displacement, maximum deflection, storey drift, maximum bending moment, maximum axial force and maximum shear force. From the observed result best type of bracing will be selected.
\end{abstract}

Keywords: Soft Storey; Bracing System; Deflection; Storey Drift; Bending Moment; Shear Force.

\section{INTRODUCTION}

Braced frames are used for trussing to resist sideway forces on structure. Trussing or triangulation, is formed by inserting corner to corner (diagonal) structural members into rectangular zones of a structural frame. It helps to stabilize the frame against sideway forces from earthquakes and strong winds. In a braced frame, bracing is usually provided in each storey of the structure to resist the forces. Beams, columns and braces arranged in such a way to form a truss. It resists lateral seismic forces by truss action and develops flexibility through inelastic action in braces. Concentrically Braced Frames (CBFs) are a class of structures resisting lateral forces through a vertical concentric truss system, the axes of the members joining concentrically at the joints as shown in Figure
Journal on Today's Ideas Tomorrow's Technologies, Vol. 4, No. 2, December 2016 pp. 97-108

CHITKARA 司 
Dhokane, S Pathak, KK

1. CBFs tend to be efficient in resisting lateral forces as they are capable to provide high strength and stiffness. These characteristics can also result in less favorable seismic response, such as higher acceleration and low drift capacity. CBFs are a common structural steel or composite system in seismic prone areas.

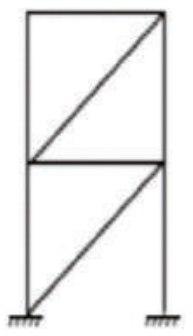

Diagonal bracing

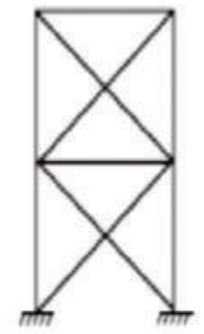

X bracing

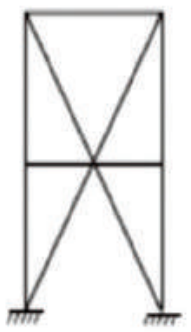

Multistory X bracing

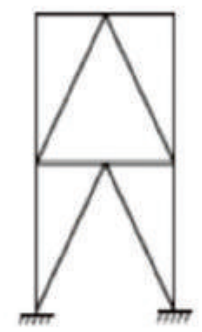

Chevron bracing

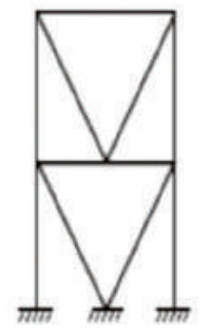

$\checkmark$ bracing

Fig.1: Types of Concentrically braced Frames

Some of the prominent literatures on the topic are given below:

Akshay Sonawane et. al. (2016), focuses on the effect of bracing system on the storey that is critical in the structure. They studied on bracing systems like cross bracing, diagonal bracing, inverted $\mathrm{V}$ bracing and $\mathrm{V}$ bracing systems and results on components like storey drift and bending moment in columns and storey displacement were calculated. Maheshraddy, Vishwanath B. Patil(2016), studied on stability analysis of multistory building with underneath satellite bus stop having Service soft storey and floating columns. In this investigation, the study of analysis of columns, shear walls, coupled component, single and multistory structure was done. For the stability of the building, arrangements like bracing system and shear system is provided or combination of both was used. The stability analysis was done in the computer software like STAAD Pro and ETAB/SAP 2000 with addition of P- $\Delta$ analysis. They concluded that, when lateral stiffness decreases, there was reduction in extreme frame building loads and square columns gives better result in parameters like storey drift, base shear and roof displacement as compared to rectangular column. Ranjit V. Surve et. al. (2015), analyzed the multistoried building with soft storey at different levels. In this study, they concentrated mainly on the finding of best place in high rise structure for the soft storey with ground level as soft storey as well as they find the natural time period of multistory building. They concluded that, number of hinges reduced by shifting of soft storey to the higher level of the building. With this, displacement as well as base shear gets increased. Yield occurrence gets reduced with the shifting of soft storey at higher level and there is formation of low intensity hinges after number of pushover steps gets 
maximum. The result for the time period was seen that, $t_{\text {eff }}$ gets decreased as the shifting of soft storey at higher level; it reduces from $2.571 \mathrm{sec}$ for $4^{\text {th }}$ floor to $2.366 \mathrm{sec}$ for $16^{\text {th }}$ floor as soft storey i.e. they conclude that soft storey gives safe result at higher level in high rise structure. Nitin Bhojkar, Mahesh Bagade (2015), studied the seismic evaluation of high rise structure by using steel bracing system. For the seismically inadequate reinforced concrete frames, the use of steel bracing systems is done for strengthening. In this study, different types of bracing systems are used and seismic analysis is done for seismic zone III as per IS1893:2002. Lateral displacement, storey drift, axial force and base shear are the main parameters which are studied. It was seen that, the structural stiffness was contributed by the $\mathrm{X}$ type of steel bracing and maximum interstorey drift of the frames also gets reduced. The bracing system gives best results in lateral stiffness, strength capacity as well as in displacement capacity. They conclude that, reduction in lateral displacement of the structure occurs up to $65 \%$ by the use of X type of bracing system. Storey drift gets reduced in X type of bracing system. There was increase in axial force for X bracing system up to $22 \%$. Hiten L. Kheni, Anuj K. Chandiwala (2014) studied on seismic response of RC building with soft stories. The strong column and weak beam construction is done for the safety of building during earthquake. Because of this concept, beams yield before columns collapse. In this research, different models are analyzed with soft storey for proper assessment of the stiffness of the storey. They concluded that displacement would be more at upper stories and less at lower stories. Ugale Ashish and Raut Harshalata (2014) studied the effect of steel plate shear wall on behavior of structure. In this paper, design and analysis of steel building is done with and without steel plate shear wall. $\mathrm{G}+6$ storey building for seismic zone III is studied and static analysis is done using STAAD Pro software. The main components which were fond out for the seismic performance are bending moment, shear force, deflection and axial force and comparison is done. The effect of shear wall is also considered. J.S Jagdish, Tejas D. Joshi (2013) studied on bracing systems on high rise steel structures. For this investigation, G+15 storied steel frame structure models with same sections and different bracing arrangements like $\mathrm{X}$ bracing, double $\mathrm{X}$ bracing, Single diagonal, K bracing and V bracings are used. STAAD Pro V8i software is used for the seismic analysis and comparison is done with different parameters. The reduction in displacement is higher in case of $\mathrm{V}$ bracing and $\mathrm{K}$ bracing compared to un-braced building due to irregularity in shape of the building. Storey drifts may increase or decrease in braced building compared to un-braced building structure. Zasiah Tafheem, Shovona Khusru (2013) studied on structural behavior of steel building with concentric and eccentric bracing. Analysis is done due to wind load, earthquake load, dead load and live load. Different bracing types such as concentric X bracing and eccentric $\mathrm{V}$ type bracings are used for the investigation using HSS sections.
A Study on the Effectiveness of Bracing Systems in Soft Storey Steel Buildings 
Dhokane, S Pathak, KK

They concluded that there is reduction in lateral displacement as compared to un-braced building. From this study, they found that concentric X bracing gives less lateral displacement as compared to eccentric V type bracing. In presence of bracing system, the inter-storey drift reduction gets increased.

\section{STRUCTURAL DETAILS}

The Steel Framed Building used in this study is ten storied $(\mathrm{G}+9)$ floors with ground $+5^{\text {th }}$ and ground $+9^{\text {th }}$ storey as soft storey to understand the realistic behavior of building under earthquake loading. The length and width of the building is $30 \mathrm{~m}$ and $18 \mathrm{~m}$ respectively. Height of the building is $32 \mathrm{~m}$ with height of typical story is $3 \mathrm{~m}$ and height of soft storey is $4 \mathrm{~m}$. Building is unsymmetrical about $\mathrm{X}$ and Z-axis. Modal damping of $5 \%$ is considered. Analytical modeling included all components that affect the strength, mass and stiffness. The non-structural components and element that do not significantly affect the building behavior were not modeled. Beams and columns are modeled as frame element and node to node joints are made. The effect of soil structure interaction is not considered in the analysis. The columns are assumed to be fixed at the ground level.

The building frame which is considered in this study is assumed to be located in Indian seismic zone IV with medium soil conditions. The frame is designed as per prevailing practice in India. Seismic loads are calculated as per IS 1893 (2002) and the design of the steel elements are carried out as per IS 800 (2007) standards. The characteristic strength of steel is considered $250 \mathrm{MPa}$. The dead load of the floors (5 m x $3 \mathrm{~m}$ panel), is taken as $2.88 \mathrm{kN} /$ $\mathrm{m}^{2}$ and live load as $3 \mathrm{kN} / \mathrm{m}^{2}$. The member load on normal stories is taken as $9 \mathrm{kN} / \mathrm{m}$ and on soft stories is $12.6 \mathrm{kN} / \mathrm{m}$. Following seismic and geometrical parameters are considered in the analysis-

Seismic zone factor, $Z=0.24$,

Response reduction factor, $\mathrm{R}=4.0$,

Importance factor, $I=1.0$

- COLUMN SECTION

I80012B50012

Ax $=387.00 \mathrm{~cm}^{2}, D=824.00 \mathrm{~mm}, B f=500.00 \mathrm{~mm}$, Tf $=12.00 \mathrm{~mm}$, $\mathrm{Tw}=12.00 \mathrm{~mm}$

- BEAM SECTION

ISMB 500

$\mathrm{Ax}=110.70 \mathrm{~cm}^{2}, \mathrm{D}=500.00 \mathrm{~mm}, \mathrm{Bf}=180.00 \mathrm{~mm}, \mathrm{Tf}=17.20 \mathrm{~mm}, \mathrm{Tw}$ $=10.20 \mathrm{~mm}$

\section{- BRACING SECTION}

ISMC 200

Structural steel- Fe 250, Density- $7850 \mathrm{Kg} / \mathrm{m}^{3}$, Young's Modulus E $=2.1 \times 10^{5} \mathrm{~N} / \mathrm{mm}^{2}$, Shear Modulus $=80000 \mathrm{~N} / \mathrm{mm}^{2}$, Poisson's Ratio- 0.3 
Concrete- M 20, Density- $2400 \mathrm{Kg} / \mathrm{m}^{3}$, Young's Modulus E= $22360 \mathrm{~N} / \mathrm{mm}^{2}$,

Shear Modulus $=8000 \mathrm{~N} / \mathrm{mm}^{2}$, Poisson's Ratio- 0.2 (Concrete properties are not used in the structural modeling but it is used in the calculation of member load and floor load).

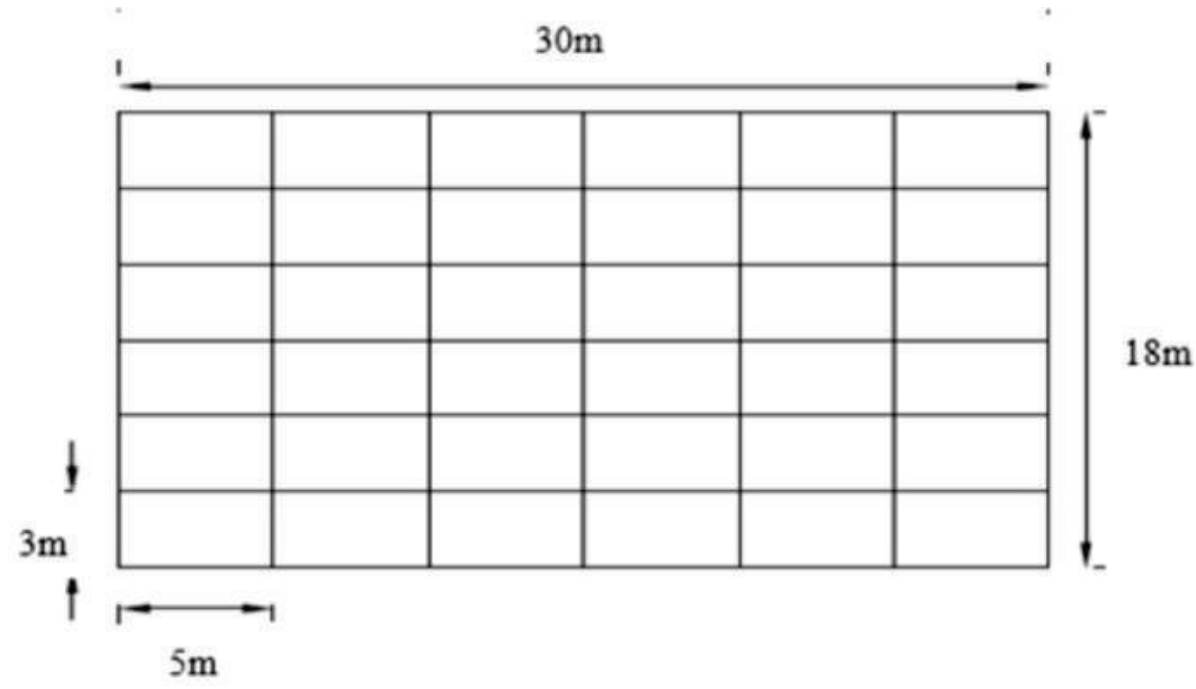

A Study on the Effectiveness of Bracing Systems in Soft Storey Steel Buildings

Fig.2: Plan of High rise steel framed building

\subsection{Types of Bracing patterns used in the study:}

In this study, 3 patterns of bracings viz. diagonal, $x$ and chevron bracings have been used. Among each type, 4 patterns have been considered which are shown in Fig. 3,4 \& 5 .

$+$
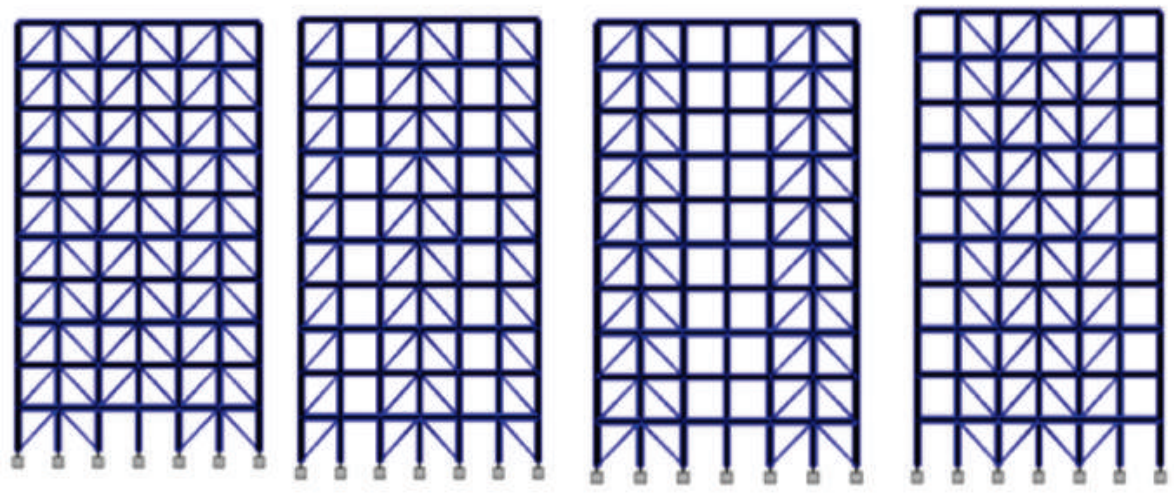

Fig.3: Different Patterns of Diagonal Brace (D1, D2, D3 \& D4) 
Dhokane, S

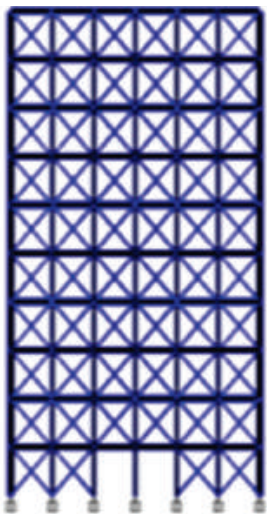

X1 BRACE

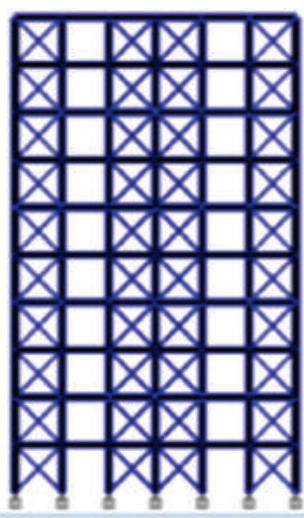

X2 BRACE

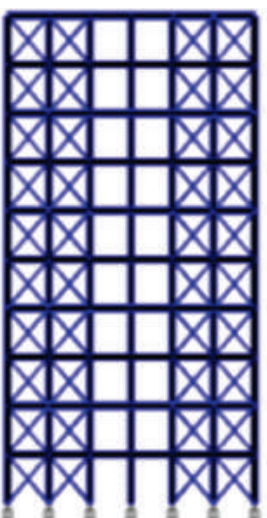

X3 BRACE

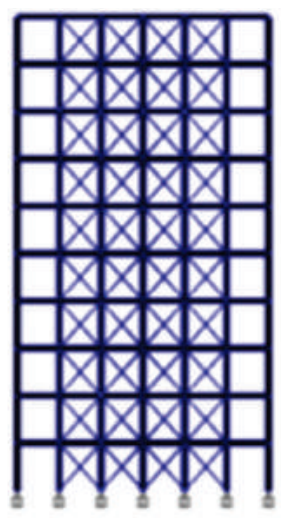

X4 BRACE

Fig.4: Different Patterns of X Brace (X1, X2, X3 \& X4)
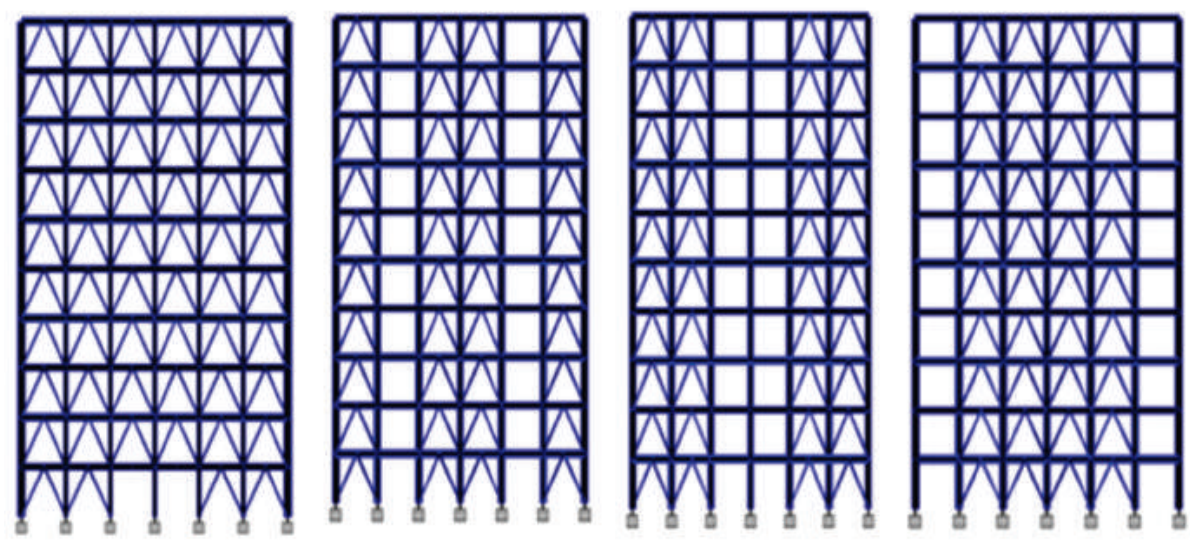

Fig.5: Different Patterns of Chevron Brace (C1, C2, C3 \& C4)

\section{RESULTS}

\subsection{Maximum Deflection}

The Maximum Deflection in the soft storey steel frame building in $\mathrm{X}$ and $\mathrm{Z}$ direction is considered for analysis in seismic zone IV. Maximum Deflection reduction is observed in $\mathrm{G}+9^{\text {th }}$ type building in $\mathrm{X} 1$ type bracing in $\mathrm{X}$ direction compared to un-braced building (Fig.6 $\& 7)$. 


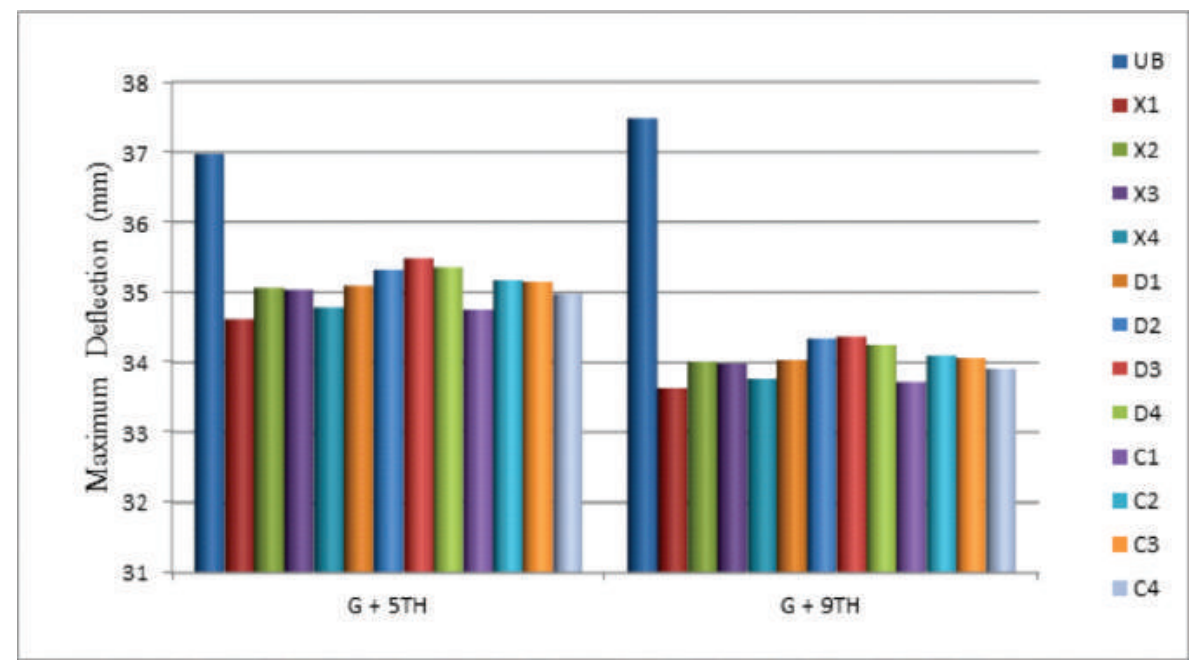

A Study on the Effectiveness of Bracing Systems in Soft Storey Steel Buildings

Fig.6: Graph of Maximum Deflection ( $\mathrm{mm}$ ) in X Direction for $\mathrm{G}+9$ Buildings

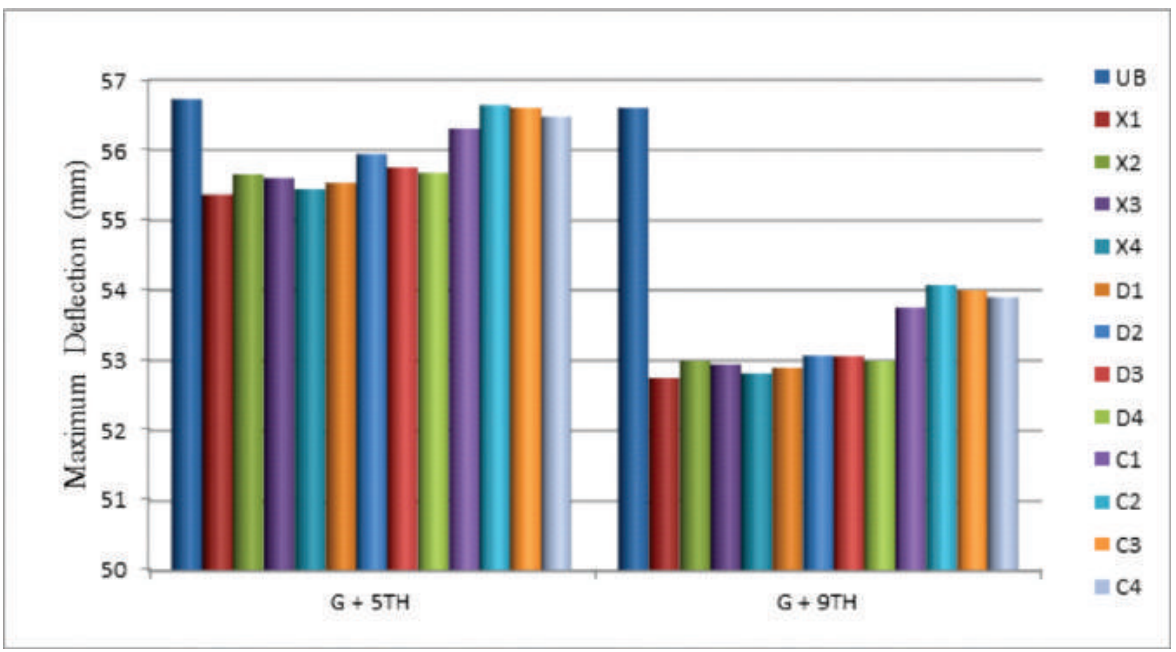

Fig.7: Graph of Maximum Deflection ( $\mathrm{mm})$ in Z Direction for $\mathrm{G}+9$ Buildings

\subsection{Storey Drift}

Maximum reduction in storey drift is observed in X1 type bracing compared to un-braced building (Fig.8,9, 10 \& 11). 
Dhokane, S

Pathak, KK

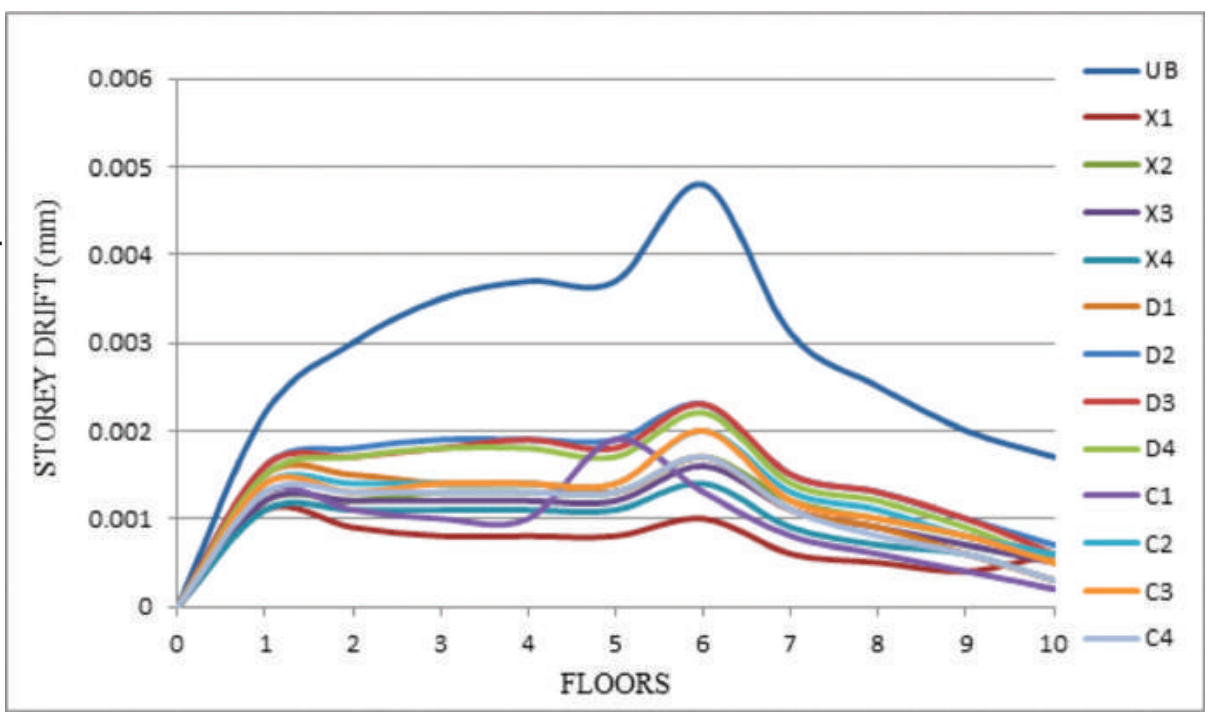

Fig.8: Graph for storey drift in $\mathrm{X}$ direction for $\mathrm{G}+5^{\text {th }}$ type building

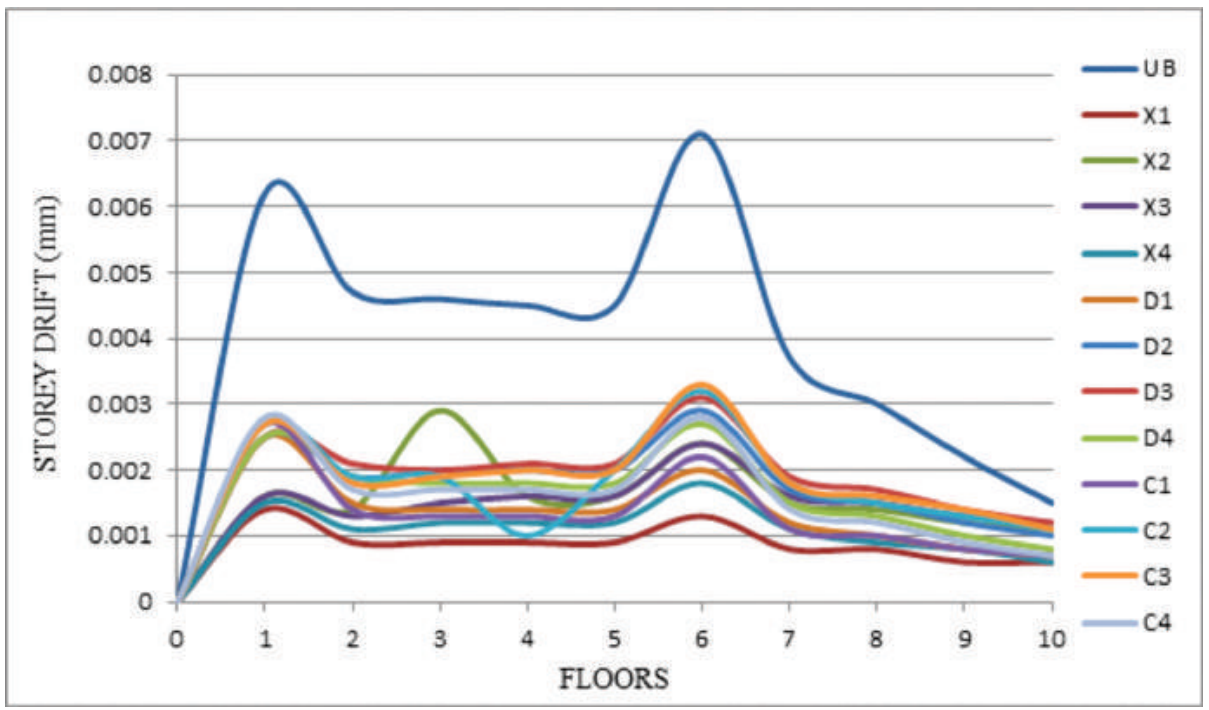

Fig.9: Graph for storey drift in $\mathrm{Z}$ direction for $\mathrm{G}+5^{\text {th }}$ type building 


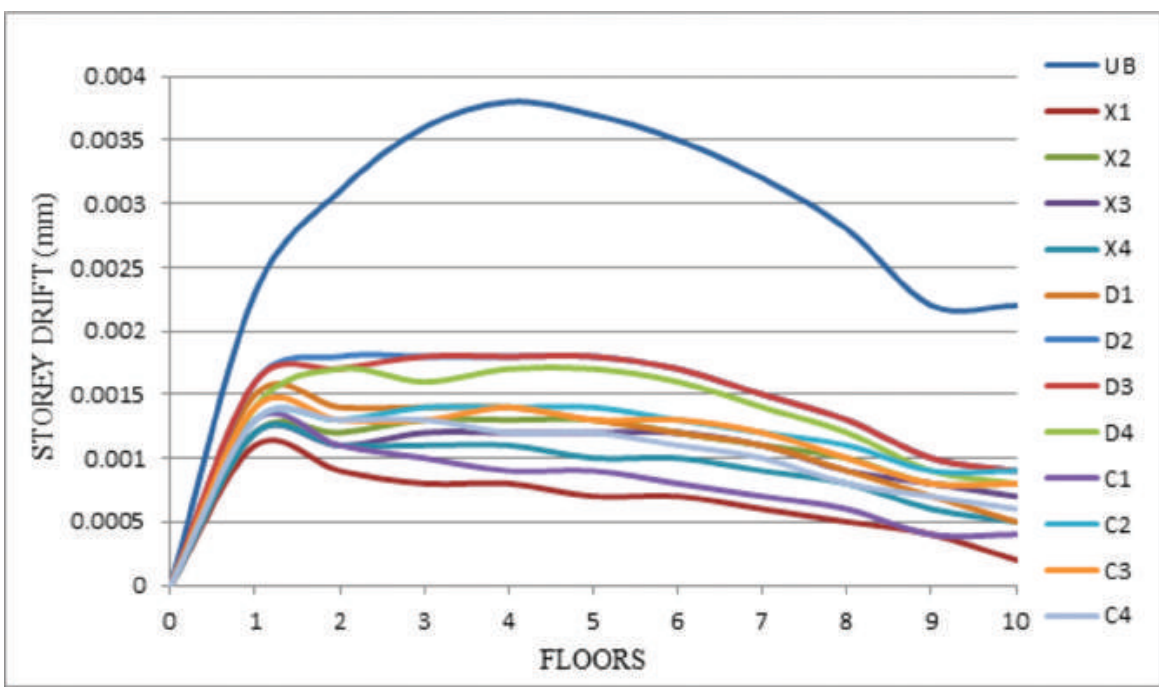

A Study on the Effectiveness of Bracing Systems in Soft Storey Steel Buildings

Fig.10: Graph for storey drift in $\mathrm{X}$ direction for $\mathrm{G}+9^{\text {th }}$ type building

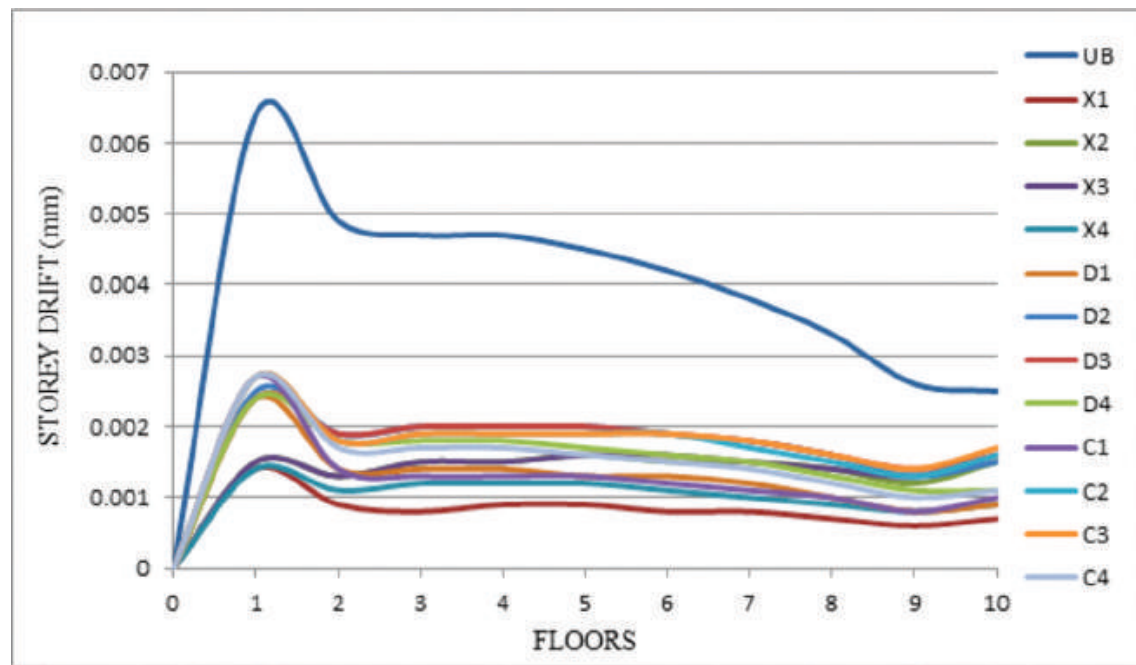

Fig.11: Graph for storey drift in $\mathrm{Z}$ direction for $\mathrm{G}+9^{\text {th }}$ type building

\subsection{Maximum Bending Moment}

Maximum reduction in maximum bending moment is observed in $\mathrm{X} 1$ type bracing in $\mathrm{G}+5^{\text {th }}$ type building as compared to un-braced building (Fig.12). 
Dhokane, S

Pathak, KK

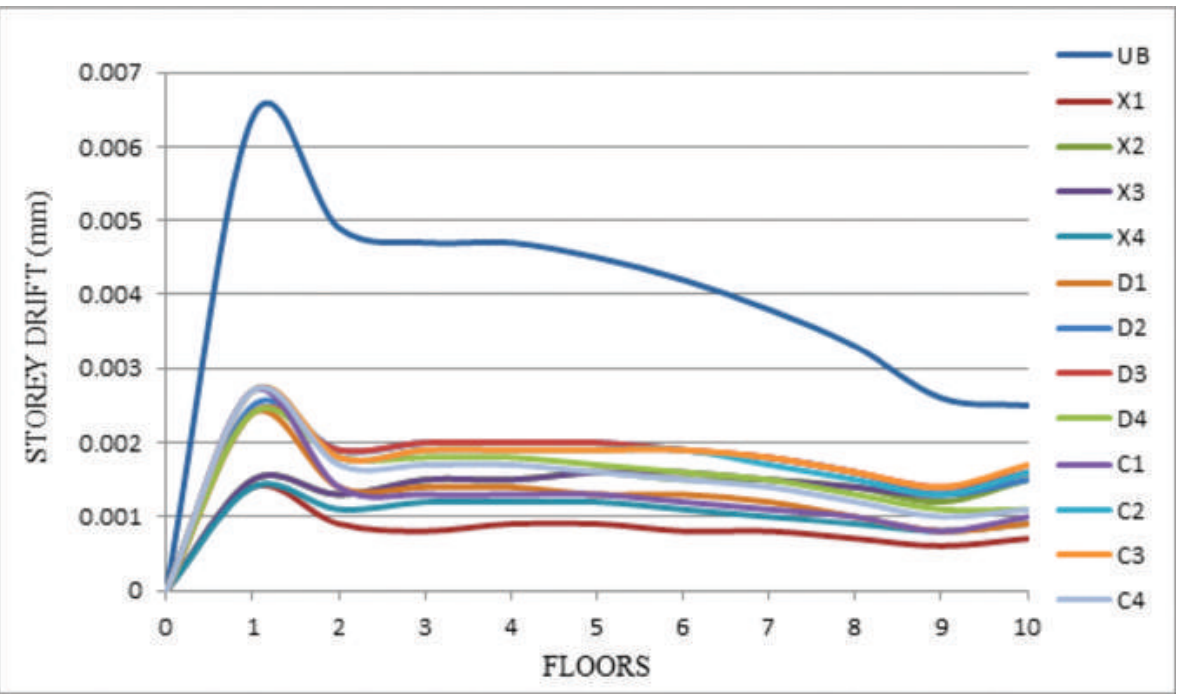

Fig.12: Graph of Maximum B.M. (kNm) for $\mathrm{G}+9$ Buildings

\subsection{Maximum Axial Force}

Maximum reduction in maximum axial force is observed in C3 type bracing in $\mathrm{G}^{+9^{\text {th }}}$ type building as compared to un-braced building (Fig.13).

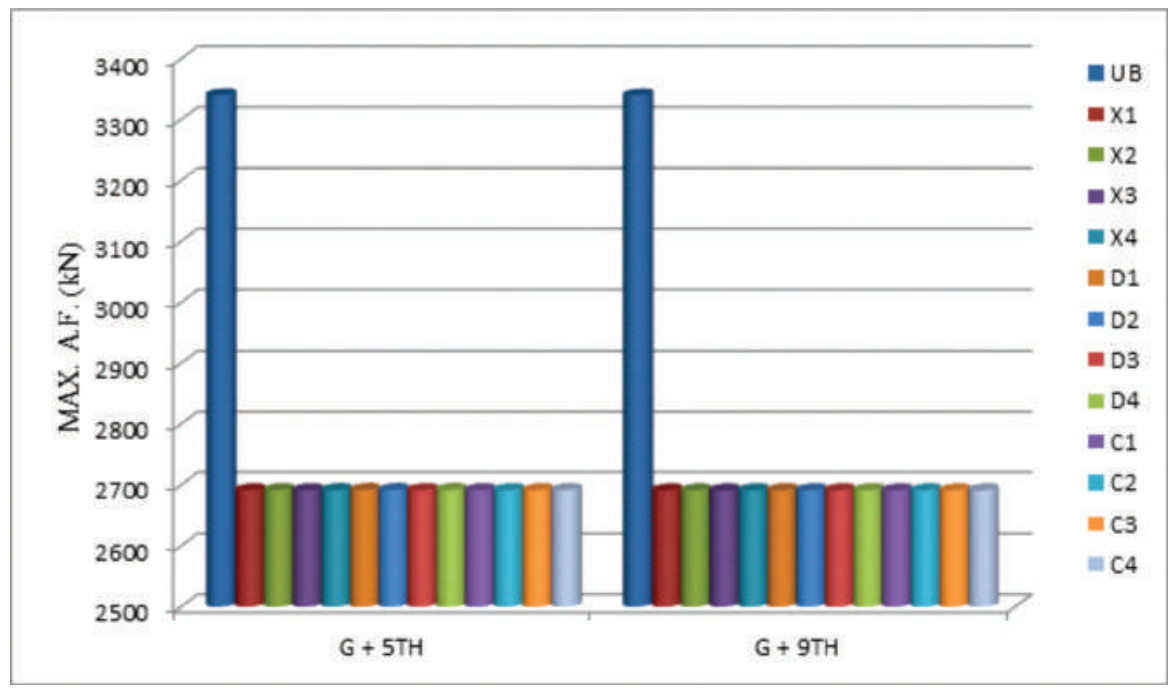

Fig.13: Graph of Maximum A.F. (kN) for $\mathrm{G}+9$ Buildings 


\subsection{Maximum Shear Force}

Maximum reduction in maximum shear force is observed in X1 type bracing in $\mathrm{G}+9^{\text {th }}$ type building as compared to un-braced building (Fig.14).

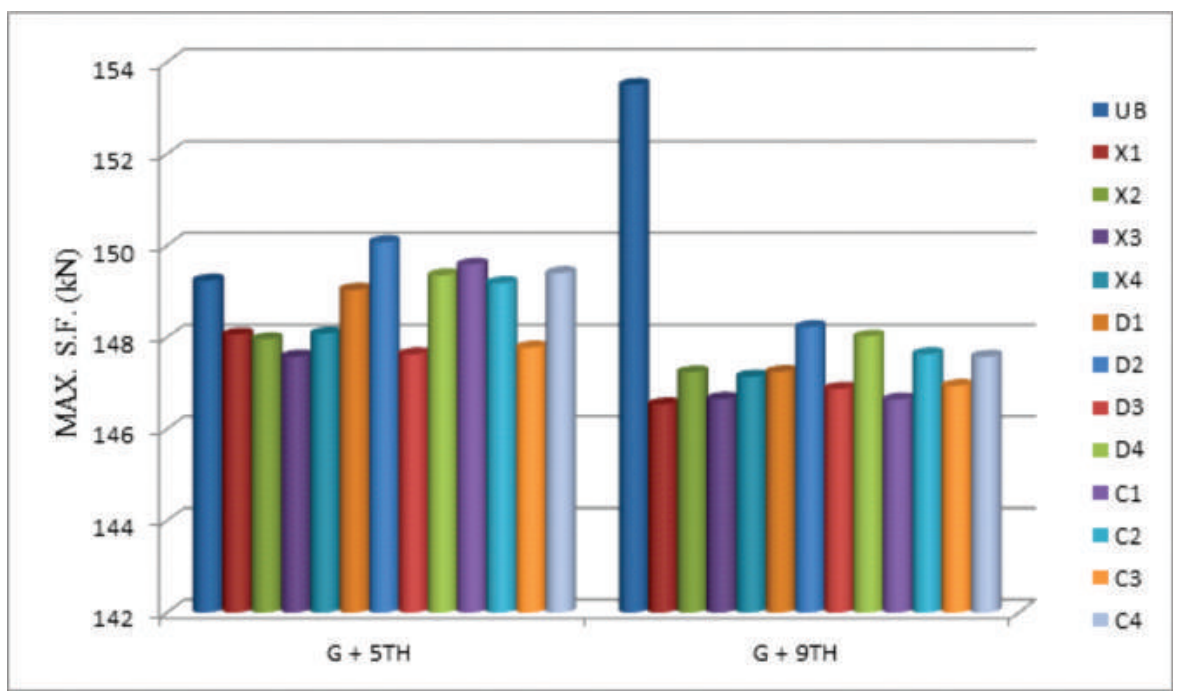

Fig.14: Graph of Maximum S.F. $(\mathrm{kN})$ for $\mathrm{G}+9$ Buildings

\section{CONCLUSIONS}

Based on the analysis results, following conclusions are drawn:

$>$ The displacement of the building decreases depending upon the different bracing system employed.

$>$ The $4^{\text {th }}$ pattern is economical having least force induced in structure as compared to un-braced building and produces more displacement as compared to $1^{\text {st }}$ pattern but within limit.

$>$ Maximum reduction in deflection occurs in $\mathrm{G}$ and $9^{\text {th }}$ storey as soft storey steel framed building as compared to $\mathrm{G}$ and $5^{\text {th }}$ storey as soft storey steel framed building. Therefore, top soft storey is preferred than the bottom soft storey.

$>$ The maximum reduction in storey drift occurs in $\mathrm{X} 1$ brace in $\mathrm{X}$ direction in $\mathrm{G}$ and $9^{\text {th }}$ type building. The use of $\mathrm{X}$ bracing reduces the storey drift by $60-90 \%$ in all bracing patterns as compared to un-brace building model.

$>$ The maximum reduction in maximum bending moment and maximum shear force occurs in $\mathrm{X} 1$ brace in $\mathrm{G}$ and $9^{\text {th }}$ type building as compared to other patterns.

$>$ The maximum reduction in the maximum axial force is observed in the $\mathrm{G}+9^{\text {th }}$ type building as compared to $\mathrm{G}+5^{\text {th }}$ type building.
A Study on the Effectiveness of Bracing Systems in Soft Storey Steel Buildings 
Dhokane, S Pathak, KK

Overall, the performance of $\mathrm{X}$ braced building is better than other two types of braced building and whole performance of $\mathrm{X} 1$ brace is better among the other patterns.

\section{REFERENCES}

1. Akshay Sonawane, Deepak Sonawane, Satish Jadhav, Rajendra Khemnar, Rohit Mahale, Dumbare, "Effect of Bracing on Critical Storey of High Rise Frame Structure", International Conference on Emerging Trends in Engineering and Management Research, pp. 1331-1336, March 2016.

2. Hiten L. Kheni, Anuj K. Chandiwala, "Seismic Response of RC Building with Soft Stories", International Journal of Trends and Technology, Vol.10, Issue 12, pp. 565-568, April 2014. http://dx.doi.org/10.14445/22315381/IJETT-V10P312.

3. IS 1893:2002, Criteria for Earthquake Resistant Design of Structure.

4. IS 800:2007, General Construction in Steel- Code in practice.

5. J.S. Jagdish, Tejas D. Joshi, "A Study on Bracing Systems on High Rise Steel Structures", International Journal of Engineering Research and Technology, Vol. 2, Issue7, pp. 16721676, July 2013.

6. Maheshraddy, Vishwanath B. Patil, “A Review on Stability Analysis of Multistory Building with Underneath Satellite Bus Stop having Service Soft Storey and Floating Columns", International Journal of Scientific Research and Development, Vol.3, Issue 12, pp. 705709, 2016.

7. Nitin Bhojkar, Mahesh Bagade, "Seismic Evaluation of High Rise Structure by using Steel Bracing System", International Journal of Innovative Science, Engineering and Technology, Vol.2, Issue 3, pp. 264-269, March 2015. http://dx.doi.org/10.5281/zenodo.61476.

8. Ranjit V. Surve, D.S. Jagtap, Y.P. Pawar, "Performance Based Analysis of Multistoried Building with Soft Storey at Different Levels", International Journal of Engineering Research and Technology, Vol.4, Issue 4, pp. 268-271, April 2015. http://dx.doi.org/10.17577/ IJERTV4IS040394.

9. Ugale Ashish B and Raut Harshalata R, "Effect of Steel Plate Shear Wall on Behavior of Structure", 2014

10. User's Manual STAAD.Pro, Bentley Software, 2013.

11. Zasiah Tafheem, Shovona Khusru, "Structural Behavior of Steel Building with Concentric and Eccentric Bracing- A Comparative Study",Vol.4, Issue 1, 2013. 